\title{
Subsidiary roles, vertical linkages and economic development: Lessons from transition economies
}

\author{
Björn Jindra ${ }^{\mathrm{a}, 1}$, Axèle Giroud ${ }^{\mathrm{b}, *}$, Joanna Scott-Kennel ${ }^{\mathrm{c}, 2}$ \\ ${ }^{a}$ Halle Institute for Economic Research, Kleine Maerkerstrasse 8, D-06108 Halle (Saale), Germany \\ ${ }^{\mathrm{b}}$ Marketing, International Business and Strategy, Manchester Business School, The University of Manchester, Booth Street East, \\ Manchester M15 6PB, United Kingdom \\ ' School of Marketing and International Business, Victoria University of Wellington, Rutherford House, 23 Lambton Quay, \\ Wellington 6001, New Zealand
}

\section{A R T I C L E I N F O}

\section{Keywords:}

MNEs

Subsidiary roles

Vertical linkages

Economic development

Transition economics

\begin{abstract}
A B S T R A C T
Vertical supply chain linkages between foreign subsidiaries and domestic firms are important mechanisms for knowledge spillovers, contributing to the economic development of host economies. This paper argues that subsidiary roles and technological competences affect the extent of vertical linkages as such as well as their potential for technological spillovers. Using survey evidence from 424 foreign subsidiaries based in transition economies, we tested for the effect of subsidiaries' autonomy, initiative, technological capability, internal and external technological embeddedness on the extent and intensity of forward and backward vertical linkages. The evidence supports our main argument that the potential of technology diffusion via vertical linkages depends on the nature of subsidiary roles. We discuss the implications for transition as well as other developing countries.
\end{abstract}

(c) 2008 Elsevier Inc. All rights reserved.

\section{Introduction}

Through technology transfer, spillovers and linkages, multinational enterprises (MNEs) are of critical importance for economic development, especially for developing and transition economies (Hoekman \& Javorcik Smarzynska, 2006; Ivarsson \& Alvstam, 2005; Kugler, 2006; UNCTAD, 2001). A widely supported explanation for this is that MNEs possess superior technological and managerial advantages, and when this knowledge is diffused to local firms, it enhances endogenous firms' own capabilities (Giroud, 2003; Hoekman \& Javorcik Smarzynska, 2006; Lall \& Narula, 2004). However, this is not an automatic process;

\footnotetext{
* Corresponding author. Tel.: +44 161275 6492; fax: +44 1613063505. E-mail addresses: bja@iwh-halle.de (B. Jindra),

axele.giroud@mbs.ac.uk (A. Giroud), joanna.scott-kennel@vuw.ac.nz (J. Scott-Kennel).

${ }^{1}$ Tel.: +49 3457753 834; fax: +49 345775369834 .

2 Tel.: +64 4463 6913; fax: +64 44635231 .
}

for instance, the potential for linkages and spillovers has been linked to individual subsidiaries' objectives and activities (Cantwell \& Mudambi, 2000; Marin \& Bell, 2006).

Studies suggest that the developmental impact of foreign subsidiaries via vertical linkages is highest when these firms demonstrate enhanced autonomy and initiative, and when they possess technological competencies (Cantwell \& Iguchi, 2005; Giroud \& Mirza, 2006; UNCTAD, 2001: 137). There is limited evidence in the literature on how subsidiaries' roles or strategies affect linkage creation in developing countries (Meyer, 2004) or indeed, in developed countries (Scott-Kennel, 2007). The aim of this paper is to contribute to the literature by investigating the relationship between subsidiaries' roles, technological competences and linkages formation in developing transition economies, thereby leading to a better understanding of when and how foreign firms contribute to the local economy and local firms' development.

This paper offers an analysis of a unique dataset on 424 foreign subsidiaries based Estonia, Slovenia, Hungary, Slovakia and Poland with in-depth data on subsidiary 
characteristics and vertical linkages to the domestic economy. We characterise subsidiary roles by the degree of autonomy in selected business functions and by the level of initiative in relation to changes in the product scope. Our focus is on technological sources of subsidiaries, differentiating between their own capability, their technological embeddedness with the MNE network as well as with the external environment in the host economy. Vertical linkages are defined as backward linkages with the local supply industries and forward linkages with customers; with a distinction between the extent of linkages formation (or how much is being bought or sold locally) and linkages intensity (or the developmental potential for local firms). With a series of OLS regression, we test for the effect of subsidiary roles, technological competences and vertical linkages. We account also for host country, industry and other firm specific effects in the corresponding estimations.

The results suggest that the potential for technology diffusion via vertical linkages depends on the nature of subsidiary roles. Higher levels of subsidiary autonomy, initiative and own technological capability increases the potential for technology diffusion to local customers. In contrast, potential diffusion to local suppliers is linked to own technological capability and intense technology sourcing from the MNE. Subsidiaries endowed with a product development mandate tend to form fewer vertical linkages locally.

Given that the evidence on vertical technological spillovers in transition economies is very mixed (see Jindra, 2006), our results hint at some possible explanatory variables at subsidiary level. These have to be put into perspective by consideration of the far reaching organisational changes in MNEs over the past few years, whereby often key suppliers with regional or global reach dominate linkages and foreign subsidiaries tend to be tightly controlled and specialised. On the other hand, MNE entry into transition economies is fairly recent and economic development ongoing. Therefore, there might be scope for changes to subsidiary roles in terms of attaining more central positions within the MNE network under the condition that technological capabilities are going to be upgraded. This is also dependent upon the technological development of local firms as the strength of external technological network in the host economy can lead to an enhanced position of the subsidiary in the MNE's internal network (Belderbos, Capannelli, \& Fukao, 2001; Cantwell \& Iguchi, 2005; Hood \& Young, 2000; Javorcik, 2004; ScottKennel \& Enderwick, 2004).

Our evidence on the link between subsidiary roles and technology diffusion relates to transition countries, which in the developing country context form a distinct group due to above average industrial employment, human capital and physical infrastructure compared to countries with similar income levels (Gros \& Suhrke, 2000; Yamin \& Sinkovics, in press). Many transition economies are developing economies, but not all developing countries are in transition from a centrally planned to a market system (Mirza \& Freeman, 2007). The countries under study in this paper are still in a development process and belong to the middle-income group (World Bank, 2007), except for Slovenia. Because the potential for vertical linkages increases with the level of development of the host economy (Giroud, 2003), middleincome countries are best suited for our study. This analysis on the relationship between subsidiary roles and vertical linkages in transition economies is further relevant to other lower and upper middle-income economies in the developing world.

The following section outlines briefly key developments in transition countries of Eastern Europe. This is followed by a review of literature on the impact of MNEs via vertical linkages on the host economy. We then argue in detail how subsidiary roles are related to vertical linkages and derive corresponding hypotheses. This part is followed by sections on methodology, estimation results, discussion of key findings, and finally, conclusions, policy implications and recommendations for future research.

\section{Vertical linkages by MNEs on host economies}

\subsection{Framing vertical linkages}

Many studies point to the technological superiority of the MNE and its unique competitive advantages to explain why the vertical linkages they create differ from those created by indigenous firms (Javorcik, 2004; Scott-Kennel \& Enderwick, 2005), unless those indigenous firms are MNEs themselves, in which case spillover on the home economy can be greater than that of foreign MNEs (Castellani \& Zanfei, 2006). Vertical linkages can be assumed to promote economic development (Hoekman \& Javorcik Smarzynska, 2006; Kugler, 2006; Lall, 1996; Moran, Graham, \& Blomström, 2005; Scott-Kennel \& Enderwick, 2005), particularly in transition economies, which exhibit high participation of MNEs in economic activity (Campos \& Kinoshita, 2002; Günther, 2005; Holland, Sass, Benacek, \& Gronicki, 2000; Uhlenbruck, 2004).

Vertical linkages embody all value chain relationships created between MNE subsidiaries and local firms in the host economy. The impact of MNEs on the local economy through vertical linkages will occur predominantly amongst industries (inter-industry impact) rather than within industries (intra-industry impact) (Kugler, 2006). Vertical linkages can be further categorised into backward and forward linkages. Backward linkages include all upstream relationships with local one-off suppliers, key suppliers or subcontractors (UNCTAD, 2001). Local suppliers gain more than the pecuniary benefits of selling their products to MNEs. They also benefit from the inter-firm exchange of technological and managerial knowledge (Giroud, 2007). Although MNEs are reluctant to compromise firm-specific assets through such exchanges with local competitors, there are mutual benefits from the transfer of selected knowledge to local suppliers of intermediate products (Hoekman \& Javorcik Smarzynska, 2006).

Forward linkages include all downstream relationships developed between foreign subsidiaries and customers, (sales) agents and distributors in a host economy. Domestic firms can benefit from spillovers and transfer of knowledge embodied in products, processes and technologies of the MNE. Many enhance their productivity as a result of access to and/or use of new enhanced products and inputs offered 
by MNEs (Driffield, Munday, \& Roberts, 2002; Dunning, 1993; Javorcik, 2004; including in services, see Miozzo \& Grimshaw, 2008).

In general, results across studies on the benefits of MNEgenerated spillovers are mixed (Bjorvatn \& Eckel, 2005; Görg \& Greenaway, 2003). The positive externalities arising from linkages have been found to be higher in the case of vertical linkages as opposed to horizontal linkages (Alfaro \& Rodríguez-Clare, 2004). In particular, the beneficial impact of linkages is highest when appropriate inter-firm knowledge and technology exchanges take place because these lead to the upgrading of local firms. Thus, one should consider first the extent to which foreign subsidiaries supply and sell locally (i.e. the extent of linkages), and second the potential technological exchanges between firms (i.e. linkages intensity).

\subsection{Focus on Eastern European economies}

Since the early 1990s, the transitional countries in Central and Eastern Europe - including Estonia, Hungary, Poland, the Slovak Republic and Slovenia - have been characterised by institutional change from planned to market economy. This process entailed policies targeted at privatisation, liberalisation and macroeconomic stabilisation (Gabrisch \& Hölscher, 2006). Post-communist countries also quickly integrated with the global, and in particular West European, economy via international trade and foreign direct investment. This process was influenced significantly by multinational companies with regard to firm restructuring (Djankov \& Murrell, 2002), private enterprise R\&D (Kalotay \& Hunya, 2000; UNCTAD, 2005), export competitiveness (Rugraff, 2006; UNCTAD, 2002), and productivity growth (Jindra, 2006; Schadler, Ashoka, Abiad, \& Leigh, 2006).

Differences in the developmental experience of individual transition economies are largely explained by initial conditions, macroeconomic policies and structural reforms (Berg et al., 1999; Fidrmuc \& Tichit, 2004). At the microlevel, MNEs and their role in the economy still need to be fully understood. With regards to linkages, foreign subsidiaries' export position has been described as fragile due to low local value added and limited linkages to domestic firms (ECE, 2001; Rugraff, 2006; Szanyi, 2006). Thus, the nexus between subsidiary roles, vertical linkages, and potential technology diffusion via spillover effects is of particular importance to fully comprehend the potential for development of foreign firms in this part of the world.

\subsubsection{Subsidiary roles and vertical linkages}

Traditionally studies examining technological externalities from FDI viewed this process as a one-way 'pipeline' of international technology transfer from parent to subsidiaries. Subsequent leakage to domestic firms was largely dependent on the absorptive capacity of domestic firms. When local firms do not possess absorptive capacity, MNEs' impact on the host economy will be limited. Recent research acknowledges that knowledge creation and accumulation within foreign subsidiaries and the extent of their interaction with domestic firms influence the extent of productivity spillovers to domestic firms (Marin \& Bell, 2006). Equally, internal competencies of subsidiaries are influenced by host country specificities, such as market size and local industrial capabilities (Lall \& Narula, 2004: 451). Other spillover studies refer to key additional subsidiaries' characteristics such as market orientation, mode of entry (Javorcik, 2004) and foreign equity participation (Gorodnichenko, Svejnar, \& Terrell, 2006) as determinants of technological externalities. To better understand the conditions behind spillover enhancement, one must therefore consider the relationship between the subsidiary and MNE strategy and subsidiary roles within the MNE.

Since the 1980s, MNEs have been increasingly perceived as inter-organizational networks of geographically dispersed and differentiated units (Ghoshal \& Bartlett, 1990; Nohria \& Ghoshal, 1994). Subsidiaries, as units of the MNE, adopt different roles as part of the wider strategic focus of the MNE, viz., innovation, global/local balance, internal differentiation, horizontal exchange of information or external and internal network (Yamin, 2005). The subsidiary's role will determine the extent to which they receive (and send) knowledge from their parent organisation (Gupta \& Govindarajan, 2000; Harzing \& Noorderhaven, 2006), their degree of independence, their ability to innovate and the subsequent relationships and networks they create in the economies where they are located.

As the roles of subsidiaries in the MNE network evolve, headquarters are more frequently receivers of knowledge from their geographically dispersed subsidiaries (Ambos, Ambos, \& Schlegelmilchb, 2006; Buckley \& Ghauri, 2004). Transfer of knowledge across units is feasible because many subsidiaries acquire strategic independence in certain aspects of their operations (e.g., R\&D activities) (Mudambi \& Navarra, 2004), or benefit from enhanced strategic roles (see Ambos et al., 2006; Andersson \& Forsgren, 2000; Birkinshaw, Hood, \& Johnson, 1998; Mudambi \& Navarra, 2004).

The resource-dependence view suggests that position of subsidiaries within their MNE network may not only be assigned by the parent firm, but evolve as the subsidiary undertakes independent and innovatory activities that enable them to develop their own unique resources and expertise locally (Birkinshaw et al., 1998). Change in a subsidiary's role over time is influenced by subsidiary capabilities and initiative (e.g., some are emerging as centres of excellence as described by Frost, Birkinshaw, \& Ensign, 2002), host country location-specific advantages and headquarters' strategies (Dörrenbächer \& Gammelgaard, 2006; Harzing \& Noorderhaven, 2006).

In this context, the technological accumulation of a subsidiary (as emphasised by Cantwell \& Mudambi, 2000; Mudambi \& Navarra, 2004; O’Donnell \& Blumentritt, 1999; Pearce, 1999) influences the ability of the firm to generate positive spillovers in the host economy (Marin \& Bell, 2006). Often, a substantial part of the potential for spillovers is created within local subsidiaries as a result of their own knowledge-creating and accumulating activities in the host economy. This paper examines the relationship between the role assigned by the parent to the subsidiary and the technological capability of the subsidiary. Thereby, we differentiate the effect on the extent and intensity of vertical linkages. The latter refers to the 
potential of vertical linkages to facilitate technology diffusion, which - in line with the literature outlined above - is assumed to be higher in case the subsidiary considers R\&D as an important source of its own competitiveness.

\subsubsection{Subsidiary autonomy and initiative}

In line with our previous discussion, two main patterns emerge from subsidiary role typologies (Schmid, Schurig, \& Kutschker, 2002): one considers subsidiary roles as being assigned by the parent company as part of a wider MNE strategy, the other allows for a level of self-determination by each individual unit and emphasises the subsidiary's strategy (Birkinshaw \& Hood, 2001). In this context, we focus on two important considerations: the degree of subsidiary autonomy and capacity to innovate (which we refer to as level of initiative).

White and Poynter (1984) argue that subsidiaries with a broad autonomy in regard to market, product, and valueadding scope (world/regional mandate subsidiary), have sufficient autonomy, authority and capabilities to generate independent competencies (Young \& Tavares, 2004: 221). They also use a wider range of local inputs creatively (Cantwell \& Iguchi, 2005: 61). We would expect that subsidiaries with autonomy of decision in terms of market, product, or value-adding scope are not only more likely to form linkages, per se, but also more intense linkages compared to subsidiaries with a narrower functional scope and levels of autonomy. Therefore, we can hypothesize:

(H1). The level of autonomy of the foreign subsidiary is positively associated with the extent and intensity of vertical linkages with domestic firms.

A subsidiary can also be viewed as a semiautonomous unit that exercises entrepreneurial or independent initiative, and improve the internal market efficiency of the MNE. External or market oriented initiatives seek to identify new customer needs, develop new suppliers or forge new alliance relationships. Internal initiatives seek to make the existing set of relationships within the MNE work more efficiently. This could include initiatives to change the value-adding scope of the subsidiary or switching from an internal to an outside supplier (Birkinshaw, 1998: 355-7). Therefore:

(H2). Initiative taken by the foreign subsidiary is positively associated with the extent and intensity of vertical linkages with domestic firms.

\subsubsection{Subsidiary technological capability and embeddedness}

Survey evidence showed that the majority of subsidiaries in transition economies are found to use technology already existent in the MNE group rather than established hostcountry specific technology, or their own R\&D (Manea \& Pearce, 2006). However, Marin and Bell (2006) suggest that the presence of knowledge creating and accumulating activities in foreign subsidiaries increases likelihood of knowledge spillovers to domestic firms. Although subsidiaries' technological capabilities are likely to depend on their role within the MNE network, in the first instance, they will also be influenced by the strategies pursued by the subsidiaries themselves as well as the business opportunities available in the local host environment. Depending on the geographical setting and history of the subsidiary, each will present a unique profile of capabilities (Birkinshaw \& Hood, 2001). The nature of linkages is related to this profile of capabilities; and linkage intensity is likely to be higher in subsidiaries with own technological capabilities. Therefore:

(H3). Technological capability developed in the foreign subsidiary is positively associated with the extent and intensity of vertical linkages with domestic firms.

In a study of inter-firm linkages, Scott-Kennel and Enderwick (2005) find that both, innovatory activities of subsidiaries as well as technology transfer from the parent to the subsidiary are positively associated with the intensity of linkages. The latter aspect could be particularly important for subsidiaries based in emerging economies that operate below the international technological frontier. More generally one could also argue that subsidiaries that are internally embedded with regard to technological knowledge within the MNE complement their own technological knowledge which in turn has potential impact on linkage intensity. Therefore:

(H4). Internal technological embeddedness by the foreign subsidiary is positively associated with the extent and intensity of vertical linkages with domestic firms.

Knowledge flows within and across firms are often related to the technological embeddedness of subsidiaries (Andersson \& Forsgren, 2000; Andersson, Forsgren, \& Holm, 2002). The subsidiary's ability to sustain and develop its competence in the local setting is dependent on the propensity to interact with local firms, share knowledge and learn from its local environment. Through the utilization of subsidiaries' external knowledge embeddedness, MNEs can increase their innovatory capabilities (Yamin \& Otto, 2004). Subsidiaries that learn from local partners in the host economy (external technological embeddedness) tend to be those that interact more with local partners (i.e. through vertical linkages). In turn, enhanced capabilities through external embeddedness will facilitate transfer of own knowledge to local partners. Therefore:

(H5). External technological embeddedness by the foreign subsidiary is positively associated with the extent and intensity of vertical linkages with domestic firms.

\section{Methodology}

MNE strategies and subsidiaries in Eastern European countries have been the subject of earlier research (Campos \& Kinoshita, 2002; Uhlenbruck, 2004), but it seems that no cross-country studies combine the analysis of both backward and forward linkages with subsidiary roles and characteristics. This can be attributed, at least in part, to the fact that few firm-level data sets exist. In fact, Dries and Swinnen (2004) remains, to our knowledge, the only study on an Eastern European country that collects firm-level data to investigate backward linkages in the Polish dairy industry. 
Table 1

Structure of supplies and sales across the sample

\begin{tabular}{|c|c|c|c|c|c|c|}
\hline & Mean & S.D. & Skewedness & S.E. & Kurtosis & S.E. \\
\hline \multicolumn{7}{|l|}{ Supplies from (as \% of total sales) } \\
\hline Foreign parent & 27.78 & 33.11 & 1.01 & 0.12 & -0.39 & 0.24 \\
\hline Other imports & 25.96 & 27.64 & 0.94 & 0.12 & -0.29 & 0.24 \\
\hline Domestic subsidiaries of foreign owner & 3.55 & 12.52 & 4.44 & 0.12 & 21.73 & 0.24 \\
\hline Domestic firms & 41.11 & 33.32 & 0.37 & 0.12 & -1.30 & 0.24 \\
\hline \multicolumn{7}{|l|}{ Sales to (as \% of total sales) } \\
\hline Foreign owner & 31.07 & 37.11 & 0.80 & 0.12 & -0.97 & 0.24 \\
\hline Other exports & 20.95 & 28.26 & 1.40 & 0.12 & 0.80 & 0.24 \\
\hline Domestic subsidiaries of foreign owner & 3.31 & 12.82 & 5.05 & 0.12 & 26.89 & 0.24 \\
\hline Domestic firms & 44.42 & 38.83 & 0.27 & 0.12 & -1.52 & 0.24 \\
\hline
\end{tabular}

\subsection{Data description}

To test our research hypotheses, we used evidence from a firm level survey conducted in Poland, Hungary, Slovakia, and Slovenia in 2002/2003. We obtained lists of foreign affiliates with at least $10 \%$ foreign ownership from multiple sources including the Estonian Investment Agency (EIA); Enterprise Estonia (EAS); Polish Agency for Foreign Investment (PAIIZ); Slovak Investment and Trade Development Agency (SARIO), Kopint-Datorg and Hungarian Trade and Development Agency (ITDH); Public Agency for Entrepreneurship and Foreign Investments (JAPTI) in Slovenia, and the Slovenian Agency for Trade and Investment Promotion (TIPO). From each country list foreign affiliates were randomly selected across all manufacturing sectors at NACE 2-digit level.

We approached a total of 2203 subsidiaries with a concise two-page questionnaire via standard mail supported by an online questionnaire. Out of this sample, 458 firms provided us with a completed questionnaire. This equates to an overall response rate of $21 \%$. The response rate was the highest in Slovenia (34.4\%), followed by Slovakia (30.2\%) and Estonia (30.0\%), Poland (18.8\%) and Hungary (11\%). A t-test on differences in industry and size distribution between survey respondents and non-respondents indicated no significant bias.

Looking at the responses, the highest proportion of foreign affiliates were from Poland (35\%), followed by Hungary (20\%), Slovakia (18\%), Slovenia (16\%) and Estonia (12\%). This is in line with a relatively high share of FDI in Poland and Hungary in the total stock of FDI in manufacturing in transition economies. The total sample represents about $4.9 \%$ of all foreign affiliates present across the five countries at the time. The share was highest for Slovenia (23.8\%), followed by Estonia (12.4\%), Poland (3.5\%) and Hungary (2.1\%). We argue that the differences in response rates across countries reflect national diversity in attitudes towards firm level surveys rather than systematic error, but acknowledge the need to be cautious when interpreting country specific effects in our results.

\subsection{Sample}

The data presented in this paper is the largest subsidiary level survey in transition countries to-date. It even exceeds the number of observations study conducted in $1997 / 1998$ by Manea and Pearce (2006) which pre- sented 144 subsidiary observations from eight transition countries. Our final useable sample consists of 424 subsidiaries. With regard to industry breakdown, the sample contains firms from all industries at NACE 2 digit level, however, the biggest shares (above 10\% share in the sample) come from electrical and optical equipment industry (NACE 30-33), metals and fabricated products (NACE 27-28), and food, beverages and tobacco (NACE 1516). The distribution of firms by size across countries was fairly balanced. Foreign subsidiaries based in Slovenia were significantly smaller and Hungarian firms significantly larger than the sample average. Across industries there are no statistically significant differences in the number of employees apart from food, beverages and tobacco (NACE 15-16) and transport equipment industries (NACE 34-35) which have a significantly higher than average number of employees per company.

\subsection{Descriptive statistics}

Table 1 shows the trade structure of subsidiaries in the sample. Local linkages vary from country to country, with an average of $44 \%$ of output sold and $41 \%$ of input bought locally. ${ }^{3}$ The share of production sold in the local market was the highest in Poland (61\%), and lowest in Slovakia (27\%) (see Table 2). The share of input bought locally was the highest in Hungary (45\% of total input bought in the local market) and lowest in Estonia (36\%). The activities of subsidiaries were closely related to the MNE network, on average subsidiaries export a third of their production to and buy just over a quarter of their input from their foreign parent.

\subsection{Variables and estimation approach}

We use two different dependent variables to proxy both extent and intensity of vertical linkages between foreign subsidiaries and domestic firms. The latter refers to the potential of vertical linkages to facilitate technology diffusion, which is assumed to be higher in case the subsidiaries consider R\&D as an important source of its

\footnotetext{
3 The value for the kurtosis of sales to domestic buyers as well as supplies from domestic sources is close to zero, however, negative. The relationship between kurtosis and standard error indicates a distribution that is not normally distributed and tails are shorter on both sides. ${ }^{3}$ The distribution for both variables is slightly right skewed.
} 
Table 2

Extent of linkages across countries

\begin{tabular}{lll}
\hline & Mean & S.D. \\
\hline Estonia & & \\
$\quad$ Forward linkages-sales to domestic firms & 35.08 & 5.39 \\
Backward linkages-sourcing from domestic firms & 35.97 & 5.23 \\
Hungary & & \\
$\quad$ Forward linkages & 43.27 & 3.99 \\
Backward linkages & 45.29 & 3.66 \\
Poland & & \\
Forward linkages & 61.97 & 2.88 \\
$\quad$ Backward Linkages & 40.47 & 2.80 \\
Slovakia & & \\
$\quad$ Forward linkages & 27.27 & 4.59 \\
Backward Linkages & 39.80 & 4.38 \\
Slovenia & & \\
$\quad$ Forward linkages & 27.23 & 3.74 \\
$\quad$ Backward Linkages & 42.11 & 3.21 \\
\hline
\end{tabular}

own competitiveness. The extent of linkage formation $\left(\mathrm{BL}_{\mathrm{i}}\right)$ is proxied by the share of supplies from domestic firms in total supplies and Backward linkage intensity $\left(\mathrm{BLI}_{\mathrm{i}}\right)$ is measured by the interaction of the share of local supplies with the importance of patents, licenses, and R\&D for subsidiary competitiveness. Correspondingly the extent of forward linkage creation $\left(\mathrm{FL}_{\mathrm{i}}\right)$ is measured as share of sales to domestic firms in total sales. Forward linkage intensity $\left(\mathrm{FLI}_{\mathrm{i}}\right)$ in turn is measured by the interaction of the share of sales to domestic firms to total sales with the importance of patents, licenses, and R\&D for subsidiary competitiveness. the number of lines of businesses: (a) on your own only, (b) mainly on your own, (c) mainly by your foreign owner, or (d) by your foreign owner only". Respondents evaluated, "How important are the following sources for patents, licenses, and R\&D?" by indicating $1=$ not important; $2=$ little important; 3 = important; 4 = very important; 5 = extremely important. The information on "your own organisation" a source for patents, licenses, and R\&D is used to approximate subsidiaries' technological capability (CapS). Corresponding data on the importance of "your foreign owner company" measures subsidiaries' internal technological embeddedness (IntEmb), on the importance of "domestic suppliers" or "domestic customers" approximates subsidiaries' external technological embeddedness (ExtEmb) for backward and forward linkages respectively.

A series of control variables was used. Country dummies (CountryDum) capture country specific effects by using Poland as control group. Greenfield investment was included as a dummy variable for entry mode (EntryDum), foreign ownership in total equity (ForEqu), market-seeking investment motive is measured as per cent of sales directed at the local market to total sales (Market), subsidiary's age as the number of years since 1990 until 2002 (Age) ${ }^{4}$; and subsidiary's size as the logarithm of the number of employees (Size). Finally, we account for industry specific effects by employing industry dummies (IndDum) at NACE 2-digit level, using NACE 30-33 (electrical and optical equipment) as a control group.

We estimated in total five different specifications using the ordinary least squares (OLS) technique ${ }^{5}$ (see box below). Specification (1) to (3) test our main explanatory variables separately due to high collinearity.

$$
\begin{aligned}
& y *=\alpha+\boldsymbol{\beta} \mathbf{S M l}_{\mathbf{i}}+\boldsymbol{\beta S M M d}+\beta \text { ForEqu }_{\mathrm{i}}+\beta \text { Market }_{\mathrm{i}}+\beta \text { Age }+\beta \text { Size }_{\mathrm{i}}+\beta \text { CountryDum }_{\mathrm{i}}+\beta \text { IndDum }_{\mathrm{i}} \\
& y *=\alpha+\boldsymbol{\beta S I P c}_{\mathbf{i}}+\beta \text { ForEqu }_{\mathrm{i}}+\beta \text { Market }_{\mathrm{i}}+\beta \text { Age }+\beta \text { Size }_{\mathrm{i}}+\beta \text { CountryDum }_{\mathrm{i}}+\beta \text { IndDum }_{\mathrm{i}} \\
& y *=\alpha+\boldsymbol{\beta} \text { CapSi }+\boldsymbol{\beta} \text { IntEmb }_{\mathrm{i}}+\boldsymbol{\beta} \text { ExtEmb }_{\mathrm{i}}+\beta \text { ForEqu }_{\mathrm{i}}+\beta \text { Market }_{\mathrm{i}}+\beta \text { Age }+\beta \text { Size }_{\mathrm{i}}+\beta \text { CountryDum }_{\mathrm{i}}+\beta \text { IndDum }_{\mathrm{i}} \\
& y *=\alpha+\beta \text { EntryDum }_{\mathrm{i}}+\beta \text { ForEqu }_{\mathrm{i}}+\beta \text { Market }_{\mathrm{i}}+\beta \text { Age }+\beta \text { Size }_{\mathrm{i}}+\beta \text { CountryDum }_{\mathrm{i}}+\beta \text { IndDum }_{\mathrm{i}} \\
& y *=\alpha+\boldsymbol{\beta} \mathrm{SMl}_{\mathrm{i}}+\boldsymbol{\beta} \mathrm{SMpd}+\boldsymbol{\beta} \mathrm{SIpc}_{\mathrm{i}}+\boldsymbol{\beta} \mathrm{CapS}_{\mathbf{i}}+\boldsymbol{\beta} \text { IntEmb }_{\mathbf{i}}+\boldsymbol{\beta} \text { ExtEmb }_{\mathbf{i}}+\beta \text { ForEqu }_{\mathrm{i}}+\beta \text { Market }_{\mathrm{i}}+\beta \text { Age }+\beta \mathrm{Size}_{\mathrm{i}} \\
& +\beta \text { CountryDum }_{\mathrm{i}}+\beta \text { IndDum }_{\mathrm{i}}
\end{aligned}
$$

We proxy subsidiaries' autonomy by asking subsidiaries to indicate, "which of the following business functions are being undertaken: (a) on your own only, (b) mainly on your own, (c) mainly by your foreign owner, or (d) by your foreign owner only." We used the correspondingly ranked variables on "supply and logistics" and "distribution and sales" (SMl) in estimation for backward and forward linkages respectively. Furthermore, we use the information on "product development" (SMpd). The latter business function was defined as the development of the product in terms of the functions the product provides as well as the technical solutions to be solved to allow the product to offer those functions. Subsidiaries' initiative for changes to product scope (SIpc) was proxied by asking the respondents to indicate, "Who has undertaken the initiative for changes in
Specification (4) tests merely for the impact of the mode of for entry (EntryDum), as this variable is not available for all observations. Specification (5) tests all main explanatory variables jointly. We estimated OLS with robust standard errors to account for heterogeneity, which was indicated by the Breusch-Pagan/Cook-Weisberg ${ }^{6}$ test. We estimated the specification (1) to (5) for each of our four

\footnotetext{
${ }^{4}$ This effect is likely to be non-linear due to the structural break of the transition. Therefore, we set the year of foundations for all subsidiaries founded prior to 1990 at 1990 .

${ }^{5}$ Given the truncated structure of our main variables we could have alternatively used log transformed value to improve model fit. However trial estimation shows no significant differences between normal OLS and OLS with log transformed dependent variables.

${ }^{6}$ The null-hypothesis was rejected in the test
} 
dependent variables i.e. extent and intensity of backward linkages as well as extent and intensity of forward linkages. ${ }^{7}$

\section{Results}

\subsection{Subsidiary autonomy}

We tested for subsidiary autonomy in terms of 1) supply and logistics (for backward linkages), 2) distribution and sales (for forward linkages), and 3) product development (for both backward and forward linkages). We found a positive relationship between subsidiary autonomy in terms of supply and logistics and the extent of backward linkages. The same relation does not hold for backward linkage intensity (see specification (1) in Table 3). The effect of subsidiaries' autonomy with regard to product development had a positive effect on the extent of backward linkages. However, the effect had the opposite sign in case of backward linkage intensity. In terms of forward linkages we found a positive effect of subsidiaries autonomy in respect to sales and distribution on the extent as well as intensity. As with backward linkages, we found a negative effect of autonomy in product development on the intensity of forward linkages (see specification (1) in Table 4). Thus the evidence is not clear cut. Therefore, the validity of Hypothesis 1 with regard to the intensity of vertical linkages was rejected for autonomy in product development.

\subsection{Subsidiary initiative}

Our results indicated that subsidiaries taking the initiative with regard to changes in product scope have a higher share of vertical linkages-both forward and backward (see specification (2) in Tables 3 and 4). The relationship was also significant and positive for forward linkages intensity but not statistically significant for backward linkages intensity. Thus, Hypothesis 2 was supported for the extent of linkages and only partially supported for linkage intensity.

\subsection{Technological capability and embeddedness}

Subsidiary technological capability was not significantly associated with the extent of forward linkages, but had a positive effect on the extent of backward linkages (specification (3) in Tables 3 and 4). However, the positive relationship was both significant and larger in size for backward as well as forward linkage intensity. Hence, Hypothesis 3 cannot be rejected for linkage intensity.

\footnotetext{
${ }^{7}$ However, when estimating the extent and intensity of backward linkages the variable approximating the investment motive (Market) is dropped from the equation. In specification (5) we include all exogenous variables and estimate stepwise backward to build an integrated model that accounts for a potential omitted variables bias. However, we use only specification (1) to (4) for interpretation because the backward estimation procedure cannot account for multicollinearity between our main exogenous variables. The estimation coefficient can be interpreted as marginal effects, thus, inform us about the size of effects.
}

Subsidiaries' internal (corporate) technological embeddedness had a negative impact on the extent of backward and forward linkages (specification (3) in Tables 3 and 4). However, the opposite is the case for the intensity of vertical linkages; i.e. the potential for technological diffusion was higher for subsidiaries, which are technologically embedded in the parent company's knowledge base. Hypothesis 4 was rejected for the extent of vertical linkages but cannot be rejected for the intensity.

We find subsidiaries' external (host country) technological embeddedness was positively and significantly associated with both the extent and intensity of forward linkages. However, there was no statistically significant effect of external technological embeddedness on either extent or intensity of backward linkages. Therefore, Hypothesis 5 can be confirmed only for forward linkages.

\subsection{Country effects}

In terms of backward linkages, Hungary and Slovenia seem to differ statistically from Poland as our control group. Hungary shows higher levels of backward linkages formation, but lower levels of backward linkages intensity. Slovenia shows only a lower level of intense backward linkages. All four countries show lower levels of extent and intensity of forward linkages compared to Poland.

\subsection{Firm specific control variables}

Only the extent of backward linkages was negatively related to Greenfield investments (see specification (4) in Tables 3 and 4). In contrast, the size of foreign ownership (equity) had a negative effect on extent and intensity of forward linkages as well as on backward linkage intensity. The estimations results show a small positive effect of subsidiary's local market orientation for extent and intensity of backward linkages. Importantly, the results confirm a positive relationship between subsidiaries age and the intensity of forward as well as backward linkages. The relationship to subsidiary size is not significant for either extent or intensity of backward linkages.

\subsection{Industry effects}

We found a number of industries differ significantly in terms of their propensity to form linkages in comparison to the control group of electrical and optical equipment producers. Foreign subsidiaries in the food, beverages, and tobacco, wood and wood products, non-metal and other mineral products, basic metal and fabricated products, machinery and equipment, and furniture and manufacturing sectors all showed a high propensity to form backward linkages. From these sectors, wood and wood products, rubber and plastics and furniture and manufacturing appear to have lower backward linkage intensity. With regard to forward linkages, we found that food, beverages, and tobacco, paper, publishing and printing, non-metal and other mineral products have a high propensity for both formation and intensity. A negative effect was indicated for subsidiaries in transport equipment. 


\begin{tabular}{|c|c|c|c|c|c|c|c|c|c|c|}
\hline & \multicolumn{10}{|c|}{ Specification } \\
\hline & \multicolumn{2}{|l|}{ (1) } & \multicolumn{2}{|l|}{$(2)$} & \multicolumn{2}{|l|}{ (3) } & \multicolumn{2}{|l|}{ (4) } & \multicolumn{2}{|l|}{ (5) } \\
\hline & $\mathrm{BL}^{\mathrm{a}}$ & $\mathrm{BLI}^{\mathrm{a}}$ & $\mathrm{BL}^{\mathrm{a}}$ & $\mathrm{BLI}^{\mathrm{a}}$ & $\mathrm{BL}^{\mathrm{a}}$ & $\mathrm{BLI}^{\mathrm{a}}$ & $\mathrm{BL}^{\mathrm{a}}$ & $\mathrm{BLI}^{\mathrm{a}}$ & $\mathrm{BL}^{\mathrm{a}}$ & $\mathrm{BLI}^{\mathrm{a}}$ \\
\hline \multicolumn{11}{|l|}{ Subsidiary autonomy } \\
\hline Supply and logistics & $19.88^{* * *}$ & 1.04 & & & & & & & $26.58^{* * *}$ & \\
\hline Product development & $25.34^{* * *}$ & $-8.75^{* * *}$ & & & & & & & $16.03^{* * *}$ & $-14.38^{* * *}$ \\
\hline \multicolumn{11}{|l|}{ Subsidiary initiative } \\
\hline Changes to product scope & & & $16.02^{* * *}$ & 1.17 & & & & & & \\
\hline \multicolumn{11}{|l|}{ Technological capability } \\
\hline Subsidiary & & & & & $9.84^{*}$ & $19.80^{* * *}$ & & & & $23.76^{* * *}$ \\
\hline \multicolumn{11}{|l|}{ Internal technological embededness } \\
\hline Foreign parent & & & & & $-20.02^{* * *}$ & $7.77^{* * *}$ & & & $-9.75^{*}$ & \\
\hline \multicolumn{11}{|l|}{ External technological embededness } \\
\hline Domestic suppliers & & & & & 9.45 & 0.67 & & & & \\
\hline \multicolumn{11}{|l|}{ Entry, motive, and governance } \\
\hline Greenfield investments (dummy = 1) & & & & & & & $-11.43^{* *}$ & 1.35 & & \\
\hline Share of foreign ownership (in\%) & -5.98 & $-6.13^{*}$ & $-9.12^{* *}$ & 3.11 & $-9.13^{*}$ & -1.54 & $-15.49^{* *}$ & -1.46 & & $-4.20^{*}$ \\
\hline Market orientation (\% of local sales) & 0.09 & $0.48^{* * *}$ & $0.12^{* *}$ & 0.47 & $0.11^{*}$ & $0.48^{* * *}$ & $0.16^{* *}$ & $0.42^{* * *}$ & $0.09^{*}$ & $0.48^{* * *}$ \\
\hline Susbidairy age (years since entry) & -0.61 & $-0.61^{*}$ & -0.43 & $0.64^{* *}$ & -0.64 & $1.51^{*}$ & $-1.48^{* *}$ & $1.11^{* * *}$ & & \\
\hline Size (number of employees in log) & 0.13 & 0.88 & 1.30 & 0.22 & -0.34 & 0.03 & -0.19 & -0.22 & & $0.60^{* *}$ \\
\hline \multicolumn{11}{|l|}{ Country dummies (Poland as control group) } \\
\hline Estland & -1.15 & -6.62 & -1.51 & $-5.71^{* *}$ & -6.12 & -2.42 & 4.38 & -4.35 & -8.37 & -2.69 \\
\hline Hungary & $7.62^{* *}$ & $-11.84^{* * *}$ & $10.54^{* *}$ & $-11.64^{* * *}$ & $9.41^{* *}$ & $-7.06^{* *}$ & $15.72^{* *}$ & $-12.36^{* * *}$ & 3.69 & $-7.30^{* * *}$ \\
\hline Slovakia & 7.91 & $-5.80^{* *}$ & 7.81 & $-4.90^{* *}$ & 3.81 & -2.97 & 10.47 & -5.08 & 4.91 & -3.91 \\
\hline Slovenia & 3.79 & $-5.39^{* *}$ & $7.94^{*}$ & $-5.82^{* *}$ & 6.81 & $6.15^{* * *}$ & 10.12 & $-5.94^{*}$ & 3.73 & $-5.53^{* *}$ \\
\hline \multicolumn{11}{|c|}{ Sector dummies (NACE 30-33 as control group, electrical and optical equipment as control group } \\
\hline NACE 15-16 Food, beverages, tobacco & $25.48^{* * *}$ & -4.57 & 27.50 *** & -3.78 & $26.39 * * *$ & -1.89 & $27.64 * * *$ & 1.36 & $25.09^{* *}$ & -1.22 \\
\hline NACE $17-18$ Textile and textile products & $-10.00^{*}$ & $-7.79 * * *$ & $-13.36^{* * *}$ & $-6.63^{* *}$ & $-14.96^{* *}$ & -1.77 & $-12.96^{* *}$ & $-6.08^{* *}$ & -9.01 & -3.91 \\
\hline NACE 19 Leather and leather products & -5.14 & -2.17 & $-14.59^{* * *}$ & -0.55 & -11.20 & -3.26 & $-9.92^{*}$ & -0.83 & -6.32 & -3.74 \\
\hline NACE 20 Wood and wood products & $26.14^{* *}$ & $-6.73^{* *}$ & $30.25^{* * *}$ & $-4.68^{*}$ & $23.77^{*}$ & -3.05 & $31.99^{* * *}$ & $-5.02^{*}$ & $23.77^{* *}$ & -6.52 \\
\hline NACE 21 Paper publishing and printing & $18.83^{*}$ & 7.77 & $20.68^{*}$ & 6.69 & $25.31^{* *}$ & 8.32 & 12.35 & 11.64 & $17.91^{*}$ & $10.78^{*}$ \\
\hline NACE 23-24 Petroleum products and chemicals & 7.26 & -6.62 & 6.39 & -5.38 & 6.40 & -3.95 & 5.38 & -5.28 & 7.64 & -5.04 \\
\hline NACE 25 Rubber and Plastic & 7.35 & $-5.54^{* *}$ & 9.01 & $-5.63^{*}$ & 6.59 & -4.06 & 6.95 & $-5.75^{*}$ & 4.44 & -2.95 \\
\hline NACE 26 Non metal and other mineral products & $21.51^{* * *}$ & 0.82 & $22.71 * * *$ & 0.83 & $22.71^{* * *}$ & 0.44 & $17.52^{* *}$ & 4.87 & $20.05^{* * *}$ & 1.15 \\
\hline NACE $27-28$ Basic metal and fabricated products & $20.99^{* * *}$ & -2.36 & $22.13^{* * *}$ & -2.44 & $18.88^{* * *}$ & -1.31 & $20.65^{* * *}$ & -4.08 & $18.73^{* * *}$ & -1.65 \\
\hline NACE 29 Machinery and equipment & $13.39^{* *}$ & -3.99 & $15.95 * * *$ & -3.58 & $12.59^{*}$ & -3.65 & $14.83^{* *}$ & -1.61 & $11.90^{*}$ & -3.78 \\
\hline NACE 34-35 Transport equipment & 4.97 & $-9.09^{* * *}$ & 2.53 & $-6.71^{* * *}$ & 5.03 & -4.37 & 1.04 & 4.05 & 5.04 & -5.61 \\
\hline NACE 36-37 Furniture and manufacturing & $33.28^{* * *}$ & $-17.22^{* * *}$ & $44.09^{* * *}$ & $-20.17^{* * *}$ & $35.99^{* * *}$ & $-13.89^{*}$ & $36.41^{* * *}$ & $-12.11^{* * *}$ & $28.83^{* * *}$ & $-11.43^{* *}$ \\
\hline \multicolumn{11}{|l|}{ Model fit } \\
\hline$n$ & 371 & 371 & 383 & 383 & 323 & 322 & 272 & 272 & 314 & 313 \\
\hline F statistic & 17.81 & 25.41 & 12.54 & 25.23 & 9.31 & 25.62 & 12.60 & 21.4 & 7.40 & 33.94 \\
\hline Prob (F-statistic) & 0.0000 & 0.0000 & 0.0000 & 0.0000 & 0.0000 & 0.0000 & 0.0000 & 0.0000 & 0.0000 & 0.0000 \\
\hline$R^{2}$ & 0.3679 & 0.6439 & 0.2871 & 0.6169 & 0.2977 & 0.6901 & 0.3176 & 0.6696 & 0.3356 & 0.7064 \\
\hline
\end{tabular}

Note: *Significant at the 0.10 level; ${ }^{* *}$ Significant at the 0.05 level; ${ }^{* * *}$ Significant at the 0.01 level.

a Dependent variables. 
Table 4

Estimation results for extent (FL) and intensity of forward linkages (FLI)

\begin{tabular}{|c|c|c|c|c|c|c|c|c|c|c|}
\hline & \multicolumn{10}{|c|}{ Specification } \\
\hline & \multicolumn{2}{|l|}{$(1)$} & \multicolumn{2}{|l|}{$(2)$} & \multicolumn{2}{|l|}{$(3)$} & \multicolumn{2}{|l|}{$(4)$} & \multicolumn{2}{|l|}{ (5) } \\
\hline & $\mathrm{FL}^{\mathrm{a}}$ & $\mathrm{FLI}^{\mathrm{a}}$ & $\mathrm{FL}^{\mathrm{a}}$ & $\mathrm{FLI}^{\mathrm{a}}$ & $\mathrm{FL}^{\mathrm{a}}$ & $\mathrm{FLI}^{\mathrm{a}}$ & $\mathrm{FL}^{\mathrm{a}}$ & $\mathrm{FLI}^{\mathrm{a}}$ & $\mathrm{FL}^{\mathrm{a}}$ & $\mathrm{FLI}^{\mathrm{a}}$ \\
\hline \multicolumn{11}{|l|}{ Subsidiary autonomy } \\
\hline Distribution and sales & $36.62 * * *$ & $17.64^{* * *}$ & & & & & & & $32.62^{* *}$ & $16.83^{* * *}$ \\
\hline Product development & 5.98 & $-11.00^{* * *}$ & & & & & & & & $-16.51^{* * *}$ \\
\hline \multicolumn{11}{|l|}{ Subsidiary initiative } \\
\hline Changes to product scope & & & $18.36^{* * *}$ & $10.25^{* * *}$ & & & & & & \\
\hline \multicolumn{11}{|l|}{ Technological capability } \\
\hline Subsidiary & & & & & -4.36 & $19.03^{* * *}$ & & & & $22.16^{* * *}$ \\
\hline \multicolumn{11}{|l|}{ Internal technological embededness } \\
\hline Foreign parent & & & & & $-5.01^{*}$ & $6.31^{*}$ & & & & \\
\hline \multicolumn{11}{|l|}{ External technological embededness } \\
\hline Domestic customers & & & & & $15.34^{* *}$ & $8.58^{*}$ & & & & \\
\hline \multicolumn{11}{|l|}{ Entry, motive, and presence } \\
\hline Greenfield investments (dummy = 1 ) & & & & & & & -2.28 & 0.65 & & \\
\hline Share of foreign ownership (in\%) & $-12.24^{* * *}$ & $-11.27^{* * *}$ & $-9.98^{* *}$ & $-7.24^{* *}$ & $-14.72^{* * *}$ & $-8.55^{* * *}$ & $-14.96^{* * *}$ & $-7.70^{* *}$ & $-11.45^{* * *}$ & $-10.07^{* * *}$ \\
\hline Age (years since entry) & 0.60 & $0.86^{* *}$ & 0.63 & $0.91^{* *}$ & 0.64 & $0.75^{* * *}$ & 0.52 & $1.35^{* * *}$ & & $0.97^{* *}$ \\
\hline Size (number of employees in log) & $-5.39^{* * *}$ & $-1.71^{* *}$ & $-5.78^{* * *}$ & $-2.33^{* *}$ & $-6.42^{* * *}$ & $-3.00^{* * *}$ & $-3.96^{* * *}$ & $-1.74^{* *}$ & $-5.91^{* * *}$ & $-2.56^{* * *}$ \\
\hline \multicolumn{11}{|l|}{ Country dummies (Poland as control group) } \\
\hline Estland & $-24.05^{* * *}$ & $-16.28^{* * *}$ & $-33.94^{* * *}$ & $-21.47^{* * *}$ & $-34.18^{* * *}$ & $-18.34^{* * *}$ & $-32.19^{* * *}$ & $-17.89^{* *}$ & $-28.60^{* * *}$ & $-17.11^{* * *}$ \\
\hline Hungary & $-15.87^{* * *}$ & $-18.68^{* * *}$ & $-18.81^{* * *}$ & $-20.01^{* * *}$ & $-17.66^{* * *}$ & $-14.49^{* * *}$ & $-16.07^{* *}$ & $-18.78^{* * *}$ & $-16.06^{* * *}$ & $-15.23^{* * *}$ \\
\hline Slovakia & $-26.32^{* * *}$ & $-18.83^{* * *}$ & $-33.58^{* * *}$ & $-20.74^{* * *}$ & $-35.73^{* * *}$ & $-19.42^{* * *}$ & $-32.63^{* * *}$ & $-19.04^{* * *}$ & $-33.36^{* * *}$ & $-19.99^{* * *}$ \\
\hline Slovenia & $-32.77^{* * *}$ & $-20.85^{* * *}$ & $-37.21^{* * *}$ & $-22.78^{* * *}$ & $-38.13^{* * *}$ & $-24.56^{* * *}$ & $-32.35^{* * *}$ & $-22.41^{* * *}$ & $-35.10^{* * *}$ & $-22.41^{* * *}$ \\
\hline \multicolumn{11}{|c|}{ Sector dummies (NACE 30-33 electrical and optical equipment as control group) } \\
\hline NACE 15-16 Food, beverages, tobacco & $38.21^{* * *}$ & $14.27^{* * *}$ & $40.81^{* * *}$ & $14.95^{* * *}$ & $37.69^{* * *}$ & $14.91^{* *}$ & $52.54^{* * *}$ & $23.75^{* * *}$ & $32.74^{* * *}$ & $14.90^{* * *}$ \\
\hline NACE $17-18$ Textile and textile products & -9.64 & $-12.24^{* * *}$ & $-10.04^{*}$ & $-11.16^{* * *}$ & $-14.47^{*}$ & $-8.38^{*}$ & -0.87 & $-6.38^{*}$ & -11.99 & $-9.39^{*}$ \\
\hline NACE 19 Leather and leather products & 6.67 & 1.14 & -4.53 & -2.34 & 5.05 & -2.68 & 0.68 & -0.28 & 12.81 & 2.79 \\
\hline NACE 20 Wood and wood products & -9.00 & $-10.01^{* *}$ & $-13.76^{*}$ & $-10.45^{* *}$ & -14.81 & $-10.52^{*}$ & -0.67 & 4.70 & -5.22 & -9.02 \\
\hline NACE 21 Paper publishing and printing & $30.76^{* * *}$ & $25.02^{* *}$ & $33.41^{* * *}$ & $21.40^{* * *}$ & $41.09^{* * *}$ & $27.08^{* * *}$ & $61.67^{* * *}$ & $38.04^{* * *}$ & $31.69^{* * *}$ & $28.29^{* * * *}$ \\
\hline NACE 23-24 Petroleum products and chemicals & $11.07^{*}$ & -1.20 & $14.97^{* *}$ & 1.01 & $20.52^{* * *}$ & 5.73 & ${ }^{*} 21.94 * * *$ & 3.43 & $14.22^{* *}$ & 1.59 \\
\hline NACE 25 Rubber and Plastic & 5.48 & -2.57 & 7.85 & -1.85 & $13.76^{*}$ & 2.21 & 12.25 & -0.24 & 6.29 & 0.18 \\
\hline NACE 26 Non metal and other mineral products & $21.34^{* * *}$ & $10.88^{*}$ & $25.29 * * *$ & $12.71^{* *}$ & $20.72^{* * *}$ & $9.39^{*}$ & $35.21^{* * *}$ & $20.09^{* * *}$ & $19.38^{* * *}$ & $10.24^{* *}$ \\
\hline NACE $27-28$ Basic metal and fabricated products & -0.85 & -2.25 & -0.37 & -2.24 & 0.98 & -0.99 & 6.05 & -1.05 & -1.28 & -1.97 \\
\hline NACE 29 Machinery and equipment & 6.46 & 0.09 & 6.93 & 0.58 & 7.17 & 1.22 & $11.51^{*}$ & 3.63 & 4.76 & -0.98 \\
\hline NACE 34-35 Transport equipment & $-11.97^{*}$ & $14.26^{* * *}$ & $-12.89^{*}$ & $-12.35^{* * *}$ & -13.50 & $-11.43^{*}$ & -0.17 & -3.77 & $-16.59^{*}$ & $-14.09^{* *}$ \\
\hline NACE 36-37 Furniture and manufacturing & 10.59 & 10.08 & $14.64^{*}$ & $-11.69^{* *}$ & 14.25 & 4.44 & 5.75 & $7.91^{*}$ & 11.45 & 3.86 \\
\hline \multicolumn{11}{|l|}{ Model fit } \\
\hline$n$ & 380 & 374 & 389 & 383 & 317 & 314 & 276 & 272 & 318 & 315 \\
\hline$F$ statistic & 36.46 & 13.97 & 29.70 & 13.26 & 21.31 & 12.28 & 14.41 & 8.29 & 18.58 & 12.06 \\
\hline Prob (F-statistic) & 0.0000 & 0.0000 & 0.0000 & 0.0000 & 0.0000 & 0.0000 & 0.0000 & 0.0000 & 0.0000 & 0.0000 \\
\hline$R^{2}$ & 0.5520 & 0.4140 & 0.4810 & 0.3778 & 0.4823 & 0.4431 & 0.4423 & 0.4184 & 0.5423 & 0.4761 \\
\hline
\end{tabular}

Note: *Significant at the 0.10 level; ${ }^{* *}$ Significant at the 0.05 level; ${ }^{* * *}$ Significant at the 0.01 level. 


\section{Discussion}

\subsection{Summary of results}

Vertical linkages have been identified as the direct mechanisms for MNEs spillovers in host developing economies, and our results enable to better understand the determinants of potential impact of foreign firms on local firms in transitional economies. We found the extent of backward linkages is positively related to subsidiary autonomy (supply and logistics; product development), subsidiaries initiatives for changes to the product scope, technological capability, but negatively related to subsidiaries' internal technological embeddedness. In contrast, the intensity of backward linkages is negatively related with autonomy in product development and positively with internal technological embeddedness. In other words, the potential for technological diffusion via backward linkages to local suppliers is arguably highest in subsidiaries that have own technological capability, source heavily technology from the MNE, and where the foreign parent decides on product development. The results for the forward linkages are very similar. However, as well as the extent of forward linkages, their intensity is positively related to subsidiary autonomy (in distribution and sales), initiative to product changes and external technological embeddedness with local customers.

The evidence supports our main argument that the extent of technology diffusion via vertical linkages depends on the nature of subsidiary strategic features (in terms of autonomy, initiatives and technological capabilities). Subsidiaries with high autonomy and initiative, as well as own technological capability generate more potential for technology diffusion to local customers. In contrast, technological diffusion to local suppliers is linked to own technological capability and intense technology sourcing from the MNE. However, if subsidiaries are endowed with a product development mandate, they tend not to form any vertical linkages with high technology diffusion potential.

The results with regard to subsidiaries technological capability are in line with a recently emerging literature that emphasizes the importance of technological capability in foreign subsidiaries for positive knowledge externalities to domestic firms (Castellani \& Zanfei, 2006; Marin \& Bell, 2006). Technological capabilities of foreign subsidiaries are closely, but not solely, related to their interaction with the MNE network. With regard to external technological embeddedness, our results partly confirm the notion that subsidiaries develop competencies by absorbing knowledge external to the firm (Yamin \& Otto, 2004 ) in case of forward linkages. This could suggest that there may be weaknesses in terms of absorptive capacity and technological capabilities in the local supply industries of transition countries that are not able to respond to scale, quality and time requirements as argued by Dyker, Higinbottom, Kofoed, and Stolberg (2006) and Szanyi (2006). Furthermore, our results would also support in respect to export oriented subsidiaries von Tunzelmann (2004) who argues that there is a 'misalignment' between foreign and domestic technological accumulation.
Finally, results from our control variables reveal some useful firm-specific features that impact upon the propensity to generate vertical linkages. In particular, we found evidence that the participation of domestic owners increases extent and intensity of vertical linkages. Subsidiaries established for market-seeking purposes have higher levels of backward linkages. Furthermore, the longer the subsidiary has been established in the host economy, the greater the potential for technological spillovers, which is in line with existing evidence. These results confirm those in earlier studies (Belderbos et al., 2001; Giroud, 2003, 2007; Holland et al., 2000). One notable result is found for subsidiary age. The length of time spent in the host economy does not lead to more linkages, but greater linkage intensity, i.e. the greater the potential for technological diffusion.

\subsection{Impact of MNEs on development}

The role of MNEs in economic development is essential. The challenge for scholars is to understand the changes in the mechanisms and dynamics of FDI-assisted development (Lall \& Narula, 2004). Initial locational features of host economies matter. Across Eastern Europe, growth has been explained by the initial conditions prevailing before individual countries adopted a market-oriented approach through appropriate macroeconomic policies and structural reforms (Berg et al., 1999; Fidrmuc \& Tichit, 2004). MNEs themselves have played a crucial role by influencing the ownership structure and the competitive environment in two ways. First as part of the firm restructuring programmes (Djankov \& Murrell, 2002), and secondly by bringing enhanced levels of entrepreneurial activities, for instance through private enterprise R\&D (Kalotay \& Hunya, 2000; UNCTAD, 2005) or firms' productivity growth (Jindra, 2006). These specific impacts on the competitive structure of transition economies are related to the transition process. This paper focuses on vertical linkages, and the development of these has been shown to be slower when governments did not adapt their policies quickly enough to encourage the private sector development (see Giroud, 2007 for a discussion on Vietnam). Differential impacts across countries are, therefore, closely related to macro-economic environment and government attitudes.

\subsection{Vertical linkages in transition or developing economies}

One can argue that promoting a thriving private sector is a difficulty for many developing countries, not solely for countries in transition. By and large, the potential gains and losses of MNEs for development are applicable to all countries wishing to access higher levels of economic development. Inter-firm relationships or vertical linkages are promoted by governments throughout the developing world, under the assumption that MNEs possess superior technological capabilities and can positively enhance the knowledge base of indigenous firms through transfer, assimilation, replication and absorption of foreign technology (Hoekman \& Javorcik Smarzynska, 2006; Lall, 1996), both within and between industries (Kugler, 2006). 
In this respect, the results presented in this paper provide insights and recommendations for other developing economies in particular for other upper middle income countries, such as Argentina, Chile, Mexico, South Africa and Botstwana, as well as selected lower middle income countries, such as Brazil, China, Indonesia and the Philippines. The deepening of vertical linkages would be too limited in the lower income group where the industrial base would not be sufficiently developed for MNEs to interact on a sufficient scale to make a significant difference. In these instances, a lack of human capital and physical infrastructure (Borensztein, De Gregorio, \& Lee, 1998; Hoskisson, Eden, Lau, \& Wright, 2000; Narula \& Dunning, 2000) are daunting obstacles. We agree with Meyer (2004), who argues that international business literature provides the basis for the analysis of FDI strategies and potential impact on emerging economies, i.e. "low and middle income countries with growth potential that makes them attractive for foreign investors" (Meyer, 2004: 260). In this context, it is not solely the political and structural elements that explain linkage creation, but the interactions between foreign and local firms. Studying linkages in Eastern European economies provides an excellent test-case of the role of MNEs in development because of the speed at which local firms have had to adapt and integrate in to a highly competitive and global economy. Hence, lessons from this study are useful in developing countries that seek contribution from FDI to upgrading capabilities in the local industry.

\subsection{MNEs technology and development}

Linkage creation and the potential for technological spillovers are also explained by the sources of technological knowledge of the subsidiary. From a technological perspective, MNEs are important players in developing economies. Governments have paid insufficient attention to the source of foreign firms' technological competences. By 2003, the share of foreign affiliates in total business enterprise $R \& D$ reached a considerable size in Hungary (62.5\%) and in the Czech Republic (46.6\%), less so in Poland (19.1\%) and Slovakia (19.0\%) (UNCTAD, 2005). When combining imported technology with local access to knowledge, local subsidiaries are able to increase their own R\&D expenditure and competences (Kalotay \& Hunya, 2000). The beneficial impact on local firms from vertical linkages is demonstrated by the fact that subsidiaries with their own technological competences generate more linkages, and thus present enhanced potential for technology transfer.

We acknowledge that linkages between foreign investors and nationally based $R \& D$ institutions are weak in the countries under study, as foreign investors simply bypassed this component of the former socialist system due to their inefficiency. This created a potential misalignment between foreign and domestic technological accumulation (von Tunzelmann, 2004). Such misalignment is not unlike the technological gap experienced by MNEs in other developing countries, and reinforces the need for these economies to invest in local technological competences, not only to attract, nurture and reinforce capabilities of foreign subsidiaries, but to increase absorptive capabilities of local firms, and thereby maximise the potential benefit from inter-firm relationships between foreign and local actors.

\subsubsection{Conclusions, policy implications and future research}

The key contribution of this paper is confirming relationships between the subsidiary's level of autonomy in its decision making process, its own initiatives and technological competences and the development of vertical linkages with suppliers and customers in host economies. Our findings suggest that the subsidiary's autonomy and technological competences are decisive for the potential developmental impact of MNEs in transition economies. Our findings are useful for several reasons. First, they suggest a way forward for future research in the area of firm-specific determinants of linkages, which should include both hostcountry and firm-specific variables. Second, they provide us with better understanding of the role played by foreign subsidiaries in the development of local firms in the transitional economies of Eastern Europe, and indeed, why their impact might not be as positive as it could be. Third, the fact that linkage formation and intensity differs by country, suggests a need to explore the differences in location-specific variables in Eastern Europe specifically, but for all developing economies. Fourth, explicit consideration of subsidiary roles and vertical linkages enables us to tease out the reasons behind the heterogeneity of FDI and, consequently, its divergent effects on host economies.

\subsection{Policy implications}

Governments throughout the developing world seek foreign technology and encourage its transfer from MNEs to local firms, often by promoting joint venture creation. Linkage creation between MNEs and local firms still receives little attention, yet some governments in Asia have started to develop programmes to promote clustering and inter-firm relations (Giroud, 2007). Our results show that governments ought to focus both on the technological competences of foreign subsidiaries themselves, but also on promoting linkages; this would involve developing policy tools to maximize linkage promotion and inter-firm technology transfer. Technological 'catch-up' is particularly important in the context of the Eastern European countries where local firms have only recently been faced with the pressures of external competition. Many such firms still need to restructure and upgrade their capital, technology and management (Dries \& Swinnen, 2004).

Given the importance of technological capabilities, the promotion of R\&D co-operation between foreign investors and domestic firms could be an appropriate policy investment to maximise the benefits of linkages. Yet, we have to keep in mind that heterogeneity of FDI also implies that other investment projects simply might not be suitable for building lasting linkages. Policymakers must, therefore, be mindful of a rise in importance of national/host features with regard to linkage formation; the criteria for 'quality' investment in terms of potential for linkage creation; encouragement of local capability building, absorptive capacity and innovation by local 
firms; and facilitation of local market orientation by foreign firms conjointly with international market orientation by domestic firms.

\subsection{Managerial implications}

Awareness of the potential impact of subsidiaries on the development of host country industry may also benefit MNEs themselves. Firstly, embeddedness in local industry engaged in a virtuous cycle of development can be conducive to asset augmentation. Where subsidiaries succeed in creating beneficial relationships with local actors, they can develop their own competences. In the long run, these benefit the MNEs by sharing knowledge accumulated and adapted to individual environments. Secondly, by adopting a dynamic perspective towards their investment in Eastern Europe, MNEs can benefit from extending mandates beyond initial market- or resourceseeking investment. Subsidiaries located in dynamic environments witnessing rapid levels of economic development, may have more opportunities and the wherewithal to adopt new roles within the global MNE network. For example, expansion and development of local and regional products and markets by subsidiaries is prompted by growth opportunities in the host and other emerging neighbouring economies.

\subsection{Suggestions for future research and limitations}

Future research might seek to further develop the areas discussed previously, and/or address the limitations of the study by employing a longitudinal approach to changes to subsidiary roles, and linking domestic and foreign firm relationships at the firm-level. A key limitation of our study resides in the respondents themselves. In future research, it would be useful to survey the parent firms themselves to fully assess the place of the subsidiary within the global network. Finally, as in many crosscountry studies, we faced difficulties in terms of response rates in different locations, which may impact on the results and therefore the generalisability of the study. Still, the authors also stress the need first, for continued emphasis on subsidiary strategy and firm characteristics in future research on linkages and spillovers, and second, to apply this topic to countries whose firms are, overall, the ones most in need and most able (due to their developing or transitional, middle income status), to benefit from vertical linkages with foreign subsidiaries.

\section{References}

Alfaro, L., \& Rodríguez-Clare, A. (2004). Multinationals and linkages: An empirical investigation. Economia, 4(2): 113-156.

Ambos, T. C., Ambos, B., \& Schlegelmilchb, B. B. (2006). Learning from foreign subsidiaries: An empirical investigation of headquarters' benefits from reverse knowledge transfers. International Business Review, 15(3): 294312.

Andersson, U., \& Forsgren, M. (2000). In search of centre of excellent: Network embeddedness and subsidiary roles in multinational corporations. Management International Review, 40(4): 329-350.

Andersson, U., Forsgren, M., \& Holm, U. (2002). The strategic impact of external networks: Subsidiary performance and competence development in the multinational corporation. Strategic Management Journal, 23: 979-996.
Belderbos, R., Capannelli, G., \& Fukao, K. (2001). Backward vertical linkages of foreign manufacturing affiliates: Evidence from Japanese multinationals. World Development, 29(1): 189-208.

Berg, A., Borenzstein, E. R., Sahay, R., \& Zettelmayer, J. (1999). The evolution of output in transition economies-Explaining the differences. IMF Working Paper, no. 99/73.

Birkinshaw, J. (1998). Corporate entrepreneurship in network organizations: How subsidiary initiative drives internal market efficiency. European Management Journal, 16(3): 355-364.

Birkinshaw, J. M., Hood, N., \& Johnson, S. (1998). Building firm-specific advantages in multinational corporations: The role of subsidiary initiative. Strategic Management Journal, 19(3): 221-242.

Birkinshaw, J., \& Hood, N. (2001). Unleash innovation in foreign subsidiaries. Harvard Business Review, 79(3): 131-137.

Bjorvatn, K., \& Eckel, C. (2005). Technological spillovers and export-platform FDI. In E. M. Graham (Ed.), Multinationals and Foreign Investment in Economic Development (Vol. Chapter 4) (pp. 85-93). Basingstoke, New York: Palgrave MacMillan.

Borensztein, E., De Gregorio, J., \& Lee, J.-W. (1998). How does foreign direct investment affect economic growth? Journal of International Economics, 45(1): 115-135.

Buckley, P. J., \& Ghauri, P. N. (2004). Globalisation, economic geography and the strategy of multinational. Journal of International Business Studies, 35(2): 81-98.

Campos, N. F., \& Kinoshita, Y. (2002). Foreign direct investment as technology transferred: Some panel evidence from the transition economies. The Manchester School, 70(3): 398-419.

Cantwell, J., \& Iguchi, C. (2005). Effects of backward linkages to local suppliers' development path: The case of the Malaysian electrical and electronics industry. In A. Giroud, A. T. Mohr, \& D. Yang (Eds.), Multinationals and Asia: Organizational and institutional relationships (pp. 5471). London, New York: Routledge.

Cantwell, J., \& Mudambi, R. (2000). The location of MNE R\&D activity: the role of investment incentives. Management International Review, 40(1): 127-148.

Castellani, D., \& Zanfei, A. (2006). Multinational firms, innovation and productivity. Cheltenham: Edward Elgar.

Djankov, S., \& Murrell, P. (2002). Enterprise restructuring in transition: A quantitative survey. Journal of Economic Literature, 40(3): 739-792.

Dörrenbächer, C., \& Gammelgaard, J. (2006). Subsidiary role development: The effect of micro-political headquarters' subsidiary negotiations on the product, market and value-added scope of foreign-owned subsidiaries. Journal of International Management, 12(3): 266-283.

Dries, L., \& Swinnen, J. F. M. (2004). Foreign direct investment, vertical integration, and local suppliers: Evidence from the Polish dairy sector. World Development, 32(9): 1525-1544.

Driffield, N., Munday, M., \& Roberts, A. (2002). Foreign direct investment, transactional linkages, and the performance of the domestic sector. International Journal of the Economics of Business, 9(3): 335351.

Dunning, J. H. (1993). Multinational Enterprises and the Global Economy. Wokingham, England: Addison-Wesley Publishing Company.

Dyker, D., Higinbottom, K., Kofoed, N., \& Stolberg, C. (2006). Analysing FDI in Central and-East Europe through case studies. In D. Dyker (Ed.), Closing the EU east west productivity gap-Foreign direct investment, competitiveness and public policy (pp. 71-92). London: Imperial College Press.

Economic Commission for Europe (ECE) (2001). Economic Survey of Europe. United Nations, New York.

Fidrmuc, J., \& Tichit, A. (2004). Mind the Break! Accounting for Changing Patterns of Growth during Transition, William Davidson Institute Working Paper Number 643.

Frost, T., Birkinshaw, J. M., \& Ensign, P. C. (2002). Centers of excellence in multinational corporations. Strategic Management Journal, 23: 9971018.

Gabrisch, H., \& Hölscher, J. (2006). The successes and failures of economic transition. Hundsmill, Basingstoke, New York: Palgrave Macmillan.

Ghoshal, S., \& Bartlett, C. A. (1990). The multinational corporation as an interorganizational network. Academy of Management Review, 15 603-625.

Giroud, A. (2003). Transnational corporations, technology and economic development: Backward linkages and knowledge transfer in South East Asia. Cheltenham, Northampton: Edward Elgar.

Giroud, A., \& Mirza, H. (2006). Multinational enterprises and local input linkages in Southeast Asia. Transnational Corporations, 15(3): 1-32.

Giroud, A. (2007). MNEs vertical linkages: The experience of Vietnam after Malaysia. International Business Review, 16(2): 159-176.

Gorodnichenko, Y., J. Svejnar \& K. Terrell (2006). Vertical and Horizontal FDI spillovers in Transition Economies: Do Institutions Matter? Mimeo, Michigan University. 
Görg, H., \& Greenaway, D. (2003). Much ado about nothing? Do domestic firms really benefit from foreign direct investment?. World Bank Research Observer, 19: 171-197.

Gros, D., \& Suhrke, M. (2000). Ten years after: What is special about transition countries? CESifo Working Paper Series No. 327.

Günther, J. (2005). Technology spillovers from foreign investors in transition economies-Are the effects still expected? Economic and Business Review for Central and South - Eastern Europe, 7(1): 5-24.

Gupta, A. K., \& Govindarajan, V. (2000). Knowledge flows within multinational corporations. Strategic Management Journal, 21(4): 473-496.

Harzing, A.-W., \& Noorderhaven, N. (2006). Knowledge flows in MNCs: An empirical test and extension of Gupta and Govindarajan's typology of subsidiary roles. International Business Review, 15(3): 195-214.

Hoekman, B., \& Javorcik Smarzynska, B. (Eds.). (2006). Global Integration and Technology Transfer. Basingstoke, New York: Palgrave MacMillan, The World Bank.

Holland, D., Sass, M., Benacek, V., \& Gronicki, M. (2000). The determinants and impact of FDI in Central and Eastern Europe: A comparison of survey and econometric evidence. Transnational Corporations, 9(3): 163-212.

Hood, N., \& Young, S. (Eds.). (2000). The Globalization of Multinational Enterprise Activity and Economic Development. Houndsmills, Basingstoke: MacMillan Press.

Hoskisson, R., Eden, L., Lau, C., \& Wright, M. (2000). Strategy in emerging economies. Academy of Management Journal, 43: 249-267.

Ivarsson, I., \& Alvstam, C. G. (2005). Technology transfer from TNCs to local suppliers in developing countries: A study of AB Volvo's truck and bus plants in Brazil, China, India, and Mexico. World Development, 33(8): $1325-1344$.

Javorcik, B. S. (2004). Does foreign direct investment increase the productivity of domestic firms? In search of spillovers through backward linkages. The American Economic Review, 94(3): 605.

Jindra, B. (2006). Theories and review of the latest research on the effects of FDI in CEE. In J. Stephan (Ed.), Technology transfer via foreign direct investment in Central and Eastern Europe - Theory, method of research - Empirical evidence (pp. 3-74). Houndsmill Basingstoke Palgrave: MacMillan.

Kalotay, K., \& Hunya, G. (2000). Privatization and foreign direct investment in Central and Eastern Europe. Transnational Corporations, 9(1): 39-66.

Kugler, M. (2006). Spillovers from foreign direct investment: Within or between industries? Journal of Development Economics, 80(2): 444477.

Lall, S. (1996). Transnational corporations and economic development. In UNCTAD (Ed.), Transnational Corporations and World Development (pp. 45-69). London, Boston: International Thomson Business Press.

Lall, S., \& Narula, R. (2004). FDI and its role in economic development: Do we need a new research agenda? The European Journal of Development Research, 16(3): 447-464.

Manea, J., \& Pearce, R. (2006). MNEs' strategies in Central and Eastern Europe: Key elements of subsidiaries behaviour. Management International Review, 46(2): 235-255.

Marin, A., \& Bell, M. (2006). Technology spillovers from foreign direct investment (FDI): The active role of MNC subsidiaries in Argentina in the 1990s. Journal of Development Studies, 42(4): 678-697.

Meyer, K. (2004). Perspectives on multinational enterprises in emerging economies. Journal of International Business Studies, 35(4): 259276.

Miozzo, M., \& Grimshaw, D. (2008). Service multinationals and forward linkages with client firms: The case of it outsourcing in Argentina and Brazil. International Business Review, 17(1): 8-27.

Mirza, H., \& Freeman, N. J. (2007). Foreign direct investment in East Asia's transitional economies: Perspectives on development and transition. International Business Review, 16(2): 141-169.

Moran, T. H., Graham, E. M., \& Blomström, M. (2005). Does Foreign Direct Investment Promote Development? Washington: Institute for International Economics.

Mudambi, R., \& Navarra, P. (2004). Is knowledge power? Knowledge flows, subsidiary power and rent-seeking within MNCs. Journal of International Business Studies, 35(5): 385-404.
Narula, R., \& Dunning, J. H. (2000). Industrial development, globalization and multinational enterprises: New realities for developing countries. Oxford Development Studies, 28(2): 141-167.

Nohria, N., \& Ghoshal, S. (1994). Differentiated fir and shared values: Alternatives for managing headquarters-subsidiary relationship. Strategic Management Journal, 15(6): 491-502.

O’Donnell, S., \& Blumentritt, T. (1999). The contribution of foreign subsidiaries to host country national competitiveness. Journal of International Management, 5(3): 187-206.

Pearce, R. D. (1999). Decentralised R\&D and strategic competitiveness: Globalised approaches to generation and use of technology in multinational enterprises (MNEs). Research Policy, 28(2-3): 157-178.

Rugraff, E. (2006). Export-oriented multinationals and the quality of international specialisation in Central European countries. The European Journal of Development Research, 18(4): 642-660.

Schadler, S., Ashoka, M., Abiad, A., \& Leigh, D. (2006). Growth in Central and Eastern European countries of the European Union. Washington, DC: International Monetary Fund.

Schmid, S., Schurig, A., \& Kutschker, M. (2002). The MNC as a network: A closer look at intra-organizational flows. Network Knowledge in International Business (pp. 40-72). Hole: Edward Elgar.

Scott-Kennel, J. (2007). Foreign direct investment and local linkages: An empirical investigation. Management International Review, 41(1): $1-27$.

Scott-Kennel, J., \& Enderwick, P. (2005). Economic upgrading and foreign direct investment: Exploring the black box of the IDP. Transnational Corporations, 14(1): 105-137.

Scott-Kennel, J., \& Enderwick, P. (2004). Inter-firm alliance and network relationships and the eclectic paradigm of international production: An exploratory analysis of quasi-internalisation at the subsidiary level. International Business Review, 3(4): 425-445.

Szanyi, M. (2006). Competitiveness and Industrial Renewal via Production Relocation by Global Multinational Networks, Working Paper, No. 166, Institute for World Economics, Hungarian Academy of Science, Budapest.

Uhlenbruck, K. (2004). Developing acquired foreign subsidiaries: The experience of MNEs in transition economies. Journal of International Business Studies, 35(5): 109-123.

UNCTAD (2002). World Investment Report 2002: Transnational Corporations and Export Competitiveness, United Nation's Conference on Trade and Competitiveness, New York and Geneva.

UNCTAD (2005). World Investment Report 2005: Transnational Corporations and the Internationalization of RED, United Nation's Conference on Trade and Competitiveness, New York and Geneva.

UNCTAD (2001). World Investment Report 2001: Promoting Linkages. New York and Geneva: United Nations.

von Tunzelmann, N. (2004). Network alignment in the catching up economies of Europe. In F. McGowan, S. Radosevic, \& N. von Tunzelmann (Eds.), The emerging industrial structure of the wider Europe, studies in global competition (pp. 23-37). Routledge.

White, R. E., \& Poynter, T. A. (1984). Strategies for foreign-owned subsidiaries in Canada. Business Quarterly, 49(2): 59-70.

World Bank (2007). Data and Statistics - A short History, http://web.world bank.org/WBSITE/EXTERNAL/DATASTATISTICS/0,contentMDK:204870 $70 \sim$ menuPK:64133156 pagePK:64133150 piPK:64133175 theSiteP K:239419,00.html, accessed June 18, 2007.

Yamin, M. (2005). Subsidiary business networks and opportunity development in multinational enterprises: A comparison of the influence of internal and external business networks. In P. N. Ghauri \& A. Hadjikhani (Eds.), Business Opportunity Development in Business Networks (pp. 91109). London: Palgrave Macmillan.

Yamin, M., \& Otto, J. (2004). Patterns of knowledge flows and MNE innovative performance. Journal of International Management, 10(2): 239-258.

Yamin, M., \& Sinkovics, R. R. (in press). Infrastructure or foreign direct investment? An examination of the implications of MNE strategy for economic development. Journal of World Business.

Young, S., \& Tavares, A. T. (2004). Centralization and autonomy: Back to the future. International Business Review, 13: 215-237. 